Jurnal Intelegensia - Vol. 06 No. 1 Januari-Juni 2018

\title{
MANAJEMEN PENGEMBANGAN KURIKULUM MUATAN LOKAL DI RA NU BANAT KUDUS
}

\section{MANAGEMENT OF LOCAL CONTENT CURRICULUM DEVELOPMENT AT RA NU BANAT KUDUS}

\author{
Siti Fadlilah \\ Pascasarjana UNISNU Jepara \\ Email: pasca@unisnu.ac.id
}

\begin{abstract}
This research aimed to describe the planning, organization, implementation, and evaluation of local content curriculum development at RA NU Banat Kudus. This research used qualitative approach and belongs to descriptive design. Data collection was done through observation, in depth interview, and documentation. The data was then analyzed by using triangulation technique. The research results showed that: 1) planning of local content curriculum development at RA NU Banat Kudus is done in the beginning of academic year and the material of local content is adjusted to the curriculum of Religion Ministry of Kudus. 2) Organizing of local content curriculum development classified by students' age and taught classically in the classroom. 3) The implementation of development including the characteristic of local content curriculum (scope of teaching material, purpose, function, etc.) and implementation strategy. 4) Evaluation of local content curriculum development in learning process is done every day (daily achievement scale).
\end{abstract}

Keywords: Curriculum Management, Curriculum Development, Local Content

\begin{abstract}
Abstrak
Penelitian ini bertujuan untuk mendeskripsikan perencanaan, pengorganisasian, pelaksanaan, serta evaluasi pengembangan kurikulum muatan lokal pada RA NU Banat Kudus. Penelitian ini menggunakan pendekatan penelitian kualitatif dengan jenis penelitian deskriptif kualitatif. Pengumpulan data dilakukan melalui observasi, wawancara mendalam, dan dokumentasi. Setelah data terkumpul secara keseluruhan, maka langkah selanjutnya adalah proses analisis data. Hasil penelitian ini mengungkapkan bahwa: 1) Perencanaan pengembangan kurikulum muatan lokal pada RA NU Banat dilakukan di awal tahun pelajaran dan materi muatan lokal disesuaikan dengan kurikulum Kementerian Agama Kabupaten Kudus. 2) Pengorganisasian pengembangan kurikulum muatan lokal dikelompokkan berdasarkan usia peserta didik dan diajarkan secara klasikal di dalam kelas. 3) Pelaksanaan pengembangan meliputi karakteristik kurikulum muatan lokal (ruang lingkup bahan ajar, tujuan, fungsi, dan sebagainya) dan strategi implementasi. 4) Evaluasi pengembangan kurikulum muatan lokal berlangsung di dalam proses pembelajaran dilakukan setiap hari (skala pencapaian harian).
\end{abstract}

Kata Kunci: Manajemen Kurikulum, Pengembangan Kurikulum, Muatan Lokal

\section{PENDAHULUAN}

Manajemen kurikulum adalah segenap proses usaha bersama untuk memperlancar pencapaian tujuan pembelajaran dengan dititikberatkan pada usaha meningkatkan kualitas interkasi belajar mengajar. Manajemen kurikulum menekankan pada suatu sistem kurikulum yang berorientasi pada produktivitas, dimana kurikulum tersebut berorientasi pada peserta didik, kurikulum dibuat agar dapat membuat peserta didik dapat mencapai tujuan hasil belajar.

Proses manajemen dalam

kurikulum sangatlah penting agar pelaksanaan pendidikan dapat berjalan dan dapat mencapai sasarannya dengan tepat. Manajemen kurikulum dapat diartikan 
sebagai suatu sistem pengelolaan kurikulum yang kooperatif, komprehensif, sistemik, dan sistematik dalam rangka mewujudkan ketercapaian tujuan kurikulum (Rusman, 2011). Otonomi yang diberikan pada lembaga pendidikan atau madrasah dalam mengelola kurikulum secara mandiri dengan memprioritaskan kebutuhan dan ketercapaian sasaran dalam visi dan misi lembaga pendidikan atau madrasah tetap berlandaskan kebijakan nasional yang telah ditetapkan.

Kegiatan pembelajaran yang diselenggarakan oleh guru merupakan bagian utama dari pendidikan formal yang syarat mutlaknya adalah adanya kurikulum sebagai pedoman. Artinya, dalam merancang program pembelajaran maupun melaksanakan proses pembelajaran guru harus selalu berpedoman pada kurikulum. Tanpa kurikulum proses pembelajaran tidak akan berjalan dengan efektif dan efisien. Maka dari itu kurikulum sangat berpengaruh dalam kegiatan pembelajaran.

Kurikulum adalah seperangkat rencana dan pengaturan mengengenai isi dan bahan pelajaran, serta cara yang digunakan sebagai pedoman penyelenggaraan pembelajaran. Isi kurikulum merupakan susunan dan bahan kajian serta pelajaran untuk mencapai tujuan penyelenggaraan satuan pendidikan. Tujuan tersebut dalam rangka upaya pencapaian tujuan pendidikan nasional (Hamalik, 2005).

Tujuan pendidikan secara umum dijabarkan dari Pancasila, yaitu meningkatkan kualitas manusia Indonesia. Manusia yang berkualitas disini adalah manusia yang beriman dan bertakaqa kepada Tuhan Yang Maha Esa, berbudi luhur, berkepribadian, berdisiplin, bekerja keras, tangguh, bertanggung jawab, mandiri, cerdas, dan terampil serta sehat jasmani dan rohani (Nurdin \& Usman, 2003).

Diantara indikator keberhasilan pendidikan adalah menghasilkan lulusan yang meningkatkan kesejahteraan ekonominya, mampu bersaing dengan masyarakat lokal atau global dan berdedikasi terhadap moral yang tinggi. Dalam bahasa yang lebih mudah dipahami bahwa pendidikan yang berkualitas mampu melahirkan generasi yang unggul dalam IMTAQ (iman dan takwa) dan IPTEK (ilmu pengetahuan dan teknologi) (Nurdin \& Usman, 2003).

Kurikulum harus bersifat fleksibel dan elastis, sehingga terbuka kesempatan untuk memberikan bahan pelajaran yang penting dan perlu bagi anak didik di tempat tertentu. Salah satunya adalah dengan adanya muatan lokal dalam proses pembelajaran di sekolah. kurikulum selain mengacu pada karakteristik peserta didik, perkembangan ilmu dan teknologi pada zamannya juga mengacu kepada kebutuhan-kebutuhan masyarakat. Penyusunan kurikulum atas dasar acuan keadaan masyarakat tersebut disebut kurikulum muatan lokal (Dakir, 2009).

Muatan lokal diartikan sebagai program pendidikan yang isi dan media penyampaiaannya dikaitkan dengan lingkungan alam, lingkungan sosial, dan lingkungan budaya, serta kebutuhan pembangunan daerah yang perlu diajarkan kepasa siswa. Isinya mencakup tentang bahan pelajaran yang digunakan. Sedangkan media penyampaian mencakuo metode dan sarana yang digunakan dalam penyampaian isi muatan lokal (Nurdin \& Usman, 2003).

Muatan lokal telah ada sejak kruikulum 1984 yang disisipkan pada bidang studi yang sesuai dan kemudian lebih diintensifkan lagi pelaksanaannya 
dalam kurikulum 1994. Dalam kurikulum 1994 muatan lokal tidak lagi disisipkan pada setiap bidang studi, tetapi menggunakan pendekatan monolitik berupa bidang studi, baik bidang studi wajib atau pilihan. Dengan adanya kebijakan otonomi daerah, kemungkinan muatan lokalnya akan lebih besar, modelnya lebih beragam dan sistemnya tidak lagi terpusat. Sehingga pengelolaannya menjadi desentralisasi (Mulyasa, 2002).

Masuknya muatan lokal dalam kurikulum nasional tidak mengubah esensi tujuan pendidikan nasional. Artinya, tujuan pendidikan nasional dan tujuan kelembagaan pendidikan tetap menjadi kerangka acuan bagi pelaksana muatan lokal (Sudjana, 2011).

Posisi muatan lokal dikuatkan lagi dengan lahirnya Peraturan Menteri Pendidikan Nasional No. 22 Tahun 2006 tentang Standar Isi Satuan Pendidikan Dasar dan Menengah, Peraturan Menteri Pendidikan Nasional No. 23 Tahun 2006 tentang Standar Kompetensi Lulusan untuk Satuan Pendidikan Dasar dan Menengah dan Peraturan Menteri Pendidikan Nasional No. 24 Tahun 2006 tentang Pelaksanan Peraturan Menteri Pendidikan Nasional No. 22 Tahun 2006 tentang Standar Isi Satuan Pendidikan Dasar dan Menengah, Peraturan Menteri Pendidikan Nasional No. 23 Tahun 2006 tentang Standar Kompetensi Lulusan untuk Satuan Pendidikan Dasar dan Menengah. Dalam peraturan tersebut dijelaskan bahwa pada dasarnya pelaksanaan kurikulum untuk tingkat satuan pendidikan dasar dan menengah seperti kurikulum muatan lokal berbasis agama dapat disesuaikan dengan kondisi dan kesiapan satuan pendidikan yang bersangkutan (Tim Redaksi Ma'arif Press, 2006).

Secara umum, muatan lokal bertujuan untuk memberikan bekal pengetahuan, keterampilan dan sikap hidup kepada peserta didik agar memiliki wawasan yang mantap tentang lingkungan dan masyarakat sesuai dengan nilai yang berlaku di daerah masing-masing dan mendukung kelangsungan pembangunan daerah serta pembangunan nasional (Mulyasa, 2007).

Dalam konteks pendidikan agama yang lebih luas dikenal dengan adanya materi khusus atau yang sering dikenal dengan istilah program pendidikan lokal yang merupakan upaya atau trobosan program pendidikan yang secara khusus disusun untuk peserta didik agar memiliki kompetensi yang dibutuhkan masyarakat dewasa ini.

Hal ini menuntut madrasah sebagai lembaga pendidikan berbasis Islam untuk mampu mengembangkan kurikulum pendidikan Islamnya baik melalui celah muatan lokalnya maupun dengan menambah waktu belajar yang dikhususkan untuk materi-materi keislaman, sesuai dengan visi dan misi lembaga pendidikan masing-masing.

Sebagai madrasah swasta yang mengiduk pada Lembaga Pendidikan Ma'arif NU Kabupaten Kudus, RA NU Banat Kudus memiliki kurikulum muatan lokal yang berisi mata pelajaran muatan lokal. Beberapa diantaranya bahkan sangat khas dan tidak dimiliki oleh lembaga pendidikan lain yang setaraf. Salah satu mata pelajaran muatan lokal yang ada di RA NU Banat adalah mata palajaran Bahasa Arab, Tauhid, dan Tarikh. Muatan lokal tersebut bertujuan untk meningkatkan kemampuan berbahasa, khususnya Bahasa Arab. 
Tujuan penelitian ini adalah mendeskripsikan perencanaan, pengorganisasian, pelaksanaan, dan evaluasi pengembangan kurikulum muatan lokal di RA NU Banat dan mendeskripsikan faktor pendukung dan faktor penghambat yang dihadapi dalam pengembangan kurikulum muatan lokal di RA NU Banat Kudus.

\section{METODE PENELITIAN}

Jenis penelitian ini merupakan penelitian deskriptif dengan pendekatan kualitatif. Jadi penelitian ini mengungkapkan situasi sosial tertentu dengan mendeskrisikan kenyataan secara benar, dibentuk oleh kata-kata berdasarkan teknik pengumpulan dan analisis data yang relevan yang diperoleh dari situasi yang alamiah (Satori \& Komariah, 2011). Pemilihan jenis penelitiani ini dikarenakan tujuan penelitian ini adalah untuk mendeskripsikan manajemen pengembangan kurikulum muatan lokal di RA NU Banat Kudus.

Teknik pengumpulan data dalam penelitian ini adalah wawancara, observasi, dan dokumentasi. Data yang telah terkumpul kemudian dianalisis dengan teknik deskriptif-eksploratif analisis. Data yang dideskripsikan memerlukan interpretasi mendalam sehingga diketahui makna dari data. Ada tiga tahapan yang dikerjakan dalam analisis data, yaitu: reduksi data, penyajian data, dan penarikan kesimpulan atau verifikasi. Data yang diperolah kemudian dianalisis interaktif. Pada penelitian ini, peneliti hanya menggunakan kriteria derajat kepercayaan (kredibilitas) sebagai pengukur keabsahan data dengan teknik perpanjangan pengamatan dan ketekunan pengamatan dan triangulasi.

\section{HASIL DAN PEMBAHASAN}

RA NU Banat Kudus merupakan salah satu RA yang maju di Kudus dan termasuk juga sekolah yang mengembangkan pembelajarann muatan lokal. Kurikulum muatan lokal merupakan program pendidikan yang disesuaikan dengan lingkungan daerah baik isi dan media penyampaian yang akan digunakan sebagai usaha dalam peningkatan dan pengembangan kebutuhan lokal sesuai dengan keadaan dan tuntutan lingkungannya. Adapun muatan lokal yang ada di RA NU Banat Kudus, yaitu materi PAI, tahfidz surat pilhan, pengenalan tahlil, tahfidz do'a harian, hafalan bacaan shalat, bahasa Inggris, tauhid, dan bahasa Arab.

Manajemen pengembangan kurikulum muatan lokal pada dasaenya ialah proses perncanaan, pengelolaan, dan pelaksanaan kurikulum muatan lokal dan peningkatan yang membutuhkan penanganan secara profesional dengan memperhatikan keseimbangan dengan kurikulum tingkat satuan pendidikan. Adapun manajemen pengembangan kurikulum muatan lokal di RA NU Banat Kudus meliputi; perencanaan, pengorganisasian, pelaksanaan, dan evaluasi.

\section{Perencanaan}

Perencanaan adalah aspek yang terpenting dan merupakan bagian yang tak terpisahkan dalam proses manajemen. Menurut Saefullah (2012) perencanaan adalah suatu konsep, rumusan yang lengkap terhadap sesuatu yang akan dicapai.

Dalam pengembangan kurikulum muatan lokal, perencanaan merupakan langkah awal yang harus ditempuh, karena perencanaan menyangkut penetapan tujuan 
dan memperkirakan cara pencapaian tujuan tesebut (Minarti, 2011).

Perencanaan pengembangan

kurikulum muatan lokal di RA NU Banat Kudus dilaksanakan di setiap awal tahun pelajaran dengan menyusun KTSP (Kurikulum Tingkat Satuan Pendidikan) terbaru dan materi muatan lokal yang disesuaikan dengan kurikulum Kementerian Agama Kabupaten Kudus dilengkapi dengan kurikulum dari BPPMNU Banat. Hal ini menjadikan RA NU Banat memiliki ciri khas dan prohtam unggulan yang selalu berkembang disesuaikan dengan perkembangan zaman serta masukan dari beberapa pihak yang berkecimpung terhadap penyelenggaraan pendidikan di RA NU Banat.

Dalam penyusunan KTSP dan materi muatan lokal melibatkan beberapa pihak di antaranya; kepala sekolah, dewan guru, komite sekolah, pengawas pendidikan madrasah kecamatan kota Kudus serta beberapa pihak terkait, dengan tetap berpegang teguh pada prinsip "Al Muhaafadhatu 'alaa Qadiimish Shaalih wal akhdzu bil Jadiidil Ashlah". Jadi, RA NU Banat selalu berinovasi terhadap hal-hal baru yang positif dan menunjuang keberhasilan pendidikan anak usia dini dengan tetap mengedepankan nilai-nilai agama Islam yang Sunni.

Adapun konsep pengembangan kurikulum muatan lokal di RA NU Banat yaitu:

a. Berpusat pada potensi, perkembangan, kebutuhan, dan kepentingan peserta didik dan lingkungannya

b. Beragam dan terpadu

c. Tanggapan terhadap perkembangan ilmu pengetahuan, teknologi dan seni

d. Relevan dengan kebutuhan kehidupan

e. Menyeluruh dan berkesinambungan

f. Belajar sepanjang hayat g. Seimbang antara kepentingan nasional dan kepentingan daerah

Adapun tujuan kurikulum muatan lokal di RA NU Banat diantaranya yaitu:

a. Belajar untuk beriman dan bertakwa kepada Tuhan Yang Maha Esa

b. Belajar untuk memahami dan menghayati

c. Belajar untuk mampu melaksanakan dan berbuat secara efektif

d. Belajar untuk hidup bersama dan berguna untuk orang lain

e. Belajar untuk membangun dan menentukan jati diri melalui proses belajar yang aktif, kreatif, efektif dan menyenangkan

Hal tersebut sesuai dengan tujuan muatan lokal menurut Depdiknas yaitu untuk memberikan bekal pengetahuan keterampilan dan sikap hidup kepada peserta didik agar memiliki wawasan yang mantap tentang lingkungan dan masyarakat sesuai dengan nilai yang berlaku di daerahnya dan mendukung kelangsungan pembangunan daerah serta pembangunan nasional.

Selain itu dalam perencanaan pembelajaran muatan lokal di RA NU Banat ada beberapa langkah yang dilakukan oleh guru muatan lokal yaitu: menyusun RPPH (Penyusuna Rencana Pelaksanaan Pembelajaran Harian), menyusun rencana pelaksanaan pembelajaran mingguan (RPPM) yang telah disesuaikan dengan program semester (promes). Kemudian guru menambahkan materi muatan lokal sesuai dengan jadwal, mengembangkan RPPH disesuaikan dengan kondisi kelas masingmasing dengan menggunakan berbagai strategi, media dan metode pembelajaran yang menyenangkan bagi anak.

Adapun bahan referensi yang digunakan dalam menyusun RPPH adalah 
dari kumpulan RPPM dan promes, buku muatan lokal RA NU Banat, buku kurikulum Kemenag Kudus, kumpulan hadits nabi, dan berbagai buku pendukung lainnya (pengenalan cara melipat, aneka media pembelajaran, alat peraga edukatif, kreasi bermain plastisin, dan lain-lain).

\section{Pengorganisaisan}

Pengorganisasian merupakan proses kegiatan penyusunan struktur organisasi sesuai dengan tujuan-tujuan, sumbersumber, dan lingkungannya. Pengorganisasian adalah suatu langkah untuk menetapkan, menggolongkan dan mengatur berbagai macam kegiatan. dengan demikian hasil pengorganisasian adalah struktur organisasi.

Pemahaman

tentang pengorganisasian sebagai salah satu fungsi manajemen akan memberikan kejelasan bahwa proses pengaturan di dalam organisasi tidak akan selesai tanpa diikuti oleh aktuasi yang berupa bimbingan kepada manusia yang berada di dalam organisasi tesebut, agar secara terus menerus dapat menjalankan kegiatan sesuai dengan tujuan yang telah ditetapkan sebelumnya.

Organisasi kurikulum merupakan pola atau desain bahan kurikulum yang tujuannya untuk mempermudah siswa dalam mempelajari bahan pelajaran serta mempermudah siswa dalam melakukan kegiatan belajar sehingga tujuan pembelajaran dapat dicapai secara efektif.

Dalam pengembangan kurikulum muatan lokal, pengorganisasian merupakan langkah yang harus ditempuh setelah proses perencanaan karena pengorganisasian sama pentingnya dengan perencaan, yang mana dalam pengorganisasian seluruh sumber harus diatur dan dipadukan sedemikian rupa untuk berjalannya suatu organisasi dalam rangkai pencapaian tujuannya.

Pengorganisasian pengembangan mata pelajaran muatan lokal di RA NU Banat Kudus ini dikelompokkan berdasarkan usia peserta didik dan diajarkan secara klasikal di dalam kelas sesuai dengan jadwal mulok yang ada.

Hal ini sesuai dengan prosedur pembentukan rombongan belajar yang diatur dalam Peraturan Menteri Pendidikan Nasional No. 58 Tahun 2009 tentang Standar Pendidikan Anak Usia Dini yang menyatakan bahwa pendidikan anak usia dini pada jalur pendidikan formal, jumlah maksimal peserta didik setiap rombongan belajar sebanyak 20 peserta didik dengan 1 orang gur TK/RA atau guru pendamping kelompok A untuk anak usia 4-5 tahun dan kelompok B untuk anak usia 5-6 tahun.

Selain pengelompokan kelas belajar, dalam pengorganisasi juga dilaksanakan pemilihan metode yang tepat dan bervariasi, pemilihan alat bermain dan sumber belajar yang ada di lingkungan, dan pemilihan teknik serta alat penilaian yang sesuai dengan kegiatan yang dilaksanakan.

Sedangkan dalam pembentukan jadwal mulok, RA NU Banat menjadwalkan hafalan materi PAI (Tauhid, Fiqih, dan lain-lain) diajarkan pada kegiatan awal setelah do'a pembuka.

Adapun untuk praktik sholat dhuha, wudhu, dan shalat dzuhur berjamaan dilaksanakan setiap hari sesuai dengan jadwal. Untuk pengenalan manasik haji, Qurban, zakat fitrah, ziarah ke makam Sunan Kudus, peringatan hari besar Islam serta kegiatan lainnya dilaksanakan sesuai jadwal kegiatan tahunan sekolah sebagaimana yang tertera dalam program kegiatan tahunan RA NU Banat. 
Kegiatan pembelajaran tersebut dapat dilaksanakan di dalam ruangan kelas atau di luar kelas dengan menggunakan metode dan teknik yang bervariasi. Hal ini dikarenakan agar tercipta suasana kelas yang menyenangkan dan dapat mudah diterima oleh peserta didik.

Dengan demikian dapat diketahui bahwa pengorganisasian pembelajaran kurikulum muatan lokal dapat berhasil apabila guru dapat menciptakan suasana pembelajaran yang mendukung dengan metode, teknik, dan strategi ynag tepat yang sesuai dengan pribadi peserta didik.

\section{Pelaksanaan}

Kurikulum muatan lokal yang merupakan program pendidikan yang disesuaikan dengan lingkungan daerah baik isi dan media penyampaian yang digunakan sebagai usaha dalam peningkatan dan pengembangan kebutuhan lokal sesuai dengan keadaan dan tuntutan lingkungannya.

Pengertian yang didapat dari hasil wawancara tidak jauh berbeda, yang mana kurikulum muatan lokal diartikan sebagai serangkaian mata pelajaran dan kumpulan pengetahuan yang diajarkan kepada peserta didik untuk mencapai pada jenjang pendidikan tertentu dengan mengedepankan kebutuhan-kebutuhan lokl dari madrasah yang disesuaikan dengan lingkungan daerah yang wajib diikuti oleh semua peserta didik.

Proses pengembangan mata pelajaran muatan lokal RA NU Banat ditangani secara profesional oleh stakeholder dengan memperhatikan keseimbagan dengan kurikulum tingkat satuan pendidikan. Begitupun juga proses pembelajarannya didasarkan pada prinsipprinsip perkembangan anak usia dini yang meliputi: a. Proses kegiatan belajar pada anak usia dini harus dilaksanakan berdasarkan prinsip belajar melalui bermain.

b. Proses kegiatan belajar pada anak usia dini dilaksanakan dalam lingkungan yang kondusif dan inovatif baik di dalam ruangan maupun di luar ruangan.

c. Proses kegiatan belajar pada anak usia dini dilaksanakan dengan pendekatan tematik dan terpadu.

d. Proses kegiatan belajar mengajar pada anak usia dini harus diarahkan pada pengembangan potensi kecerdasan secara menyeluruh dan terpadu.

Selain itu, Oemar Hamalik dalam Susilo (2007) membagi prinsip pengembangan kurikulum menjadi 8 macam, antara lain:

a. Prinsip berorientasi pada tujuan, artinya pengembangan kurikulum diarahkan untuk mencapai tujuan tertentu.

b. Prinsip relevansi (kesesuaian). Kurikulum muatan lokal dikembangkan sesuai kebutuhan dan keadaan masyarakat.

c. Prinsip efisiensi dan efektivitas, artinya pengembangan kurikulum harus mempertimbangkan segi efisiensi dalam pendayagunaan dana, waktu, tenaga dan sumber-sumber yang tersedia agar dapat mencapai hasil yang optimal.

d. Prinsip fleksibilitas (keluwesan), artinya kurikulum yang dikembangkan hendaknya bersikap luwes, mudah disesuaikan berdasarkan tuntutan dan keadaan lembaga pendidikan, tidak statis dan kaku.

e. Prinsip kontinuitas, artinya kurikulum secara berkesinambungan jadi bagianbagian, aspek-aspek, materi dan bahan kajian disusun secara berurutan, tidak terlepas-lepas, melainkan satu sama lain memiliki hubungan fungsional yang bermakna, sesuai dengan jenjang 
pendidikan, struktur dalam satuan pendidikan.

f. Prinsip keseimbangan, artinya kurikulum dikembangkan dengan memperhatikan keseimbangan secara proporsional dan fungsional antara berbagai program dan sub-program, antara semua mata pelajaran, serta antara aspek-aspek perilaku yang ingin dikembangkan.

g. Prinsip keterpaduan, maksudnya bahwa kurikulum dirancang dan dilaksanakan berdasarkan keterpaduan.

h. Prinsip mutu, artinya pengembangan kurikulum khususnya kurikulum muatan lokal berorientasi pada pendidikan mutu, yang berarti bahwa pelaksanaan pembelajaran yang bermutu ditentukan oleh derajat mutu guru, kegiatan belajar mengajar, dan peralatan/media yang bermutu.

Pelaksanaan mata pelajaran muatan lokal diarahkan kepada kemajuankemajuan yang bersifat positif, dimana mata pelajaran muatan lokal disesuaikan dengan kebutuhan anak, karena menurut pertimbangan sekolah, kurikulum muatan lokal dianggap dapat memenuhi tuntutan lingkungan. Karena kurikulum muatan lokal disini merupakan sebuah upaya untuk mengakomodasi dan sekaligus mengenalkan kepada peserta didik dengan lingkungan alam, sosial, dan kebudayaan. Pengajaran muatan lokal akan memberikan pengetahuan yang lebih mendalam kepada peserta didik akan lebih mengenal dan dapat melestarikan serta mengembangkan potensi yang dimiliki daerahnya.

Pelaksanaan pembelajaran muatan lokal di RA NU Banat diajarkan secara di dalam kelas sesuai dengan jadwal mulok yang ada. Untuk materi PAI (Tauhid, Fiqih, Tarikh, Tahfidz, surat pendek, Hadits Nabi, do'a harian dll) diajarkan pada kegiatan awal setelah do'a pembuka, untuk hafalan surat Yaasin dan Al-Mulk dilaksanakan setelah shalat Dhuha, dan pengenalan tahlil dilaksanakan setiap hari Kamis. Adapun untuk praktik sholat dhuha, praktik wudlu dan sholat dhuhur berjamaah dilaksanakan setiap hari sesuai dengan jadwal dan hari Kamis.

Metode pembelajarannya juga variatif disesuaikan dengan perkembangan anak dan juga pendekatannya melalui bermain dan alat bantu peraga untuk memudahkan anak usia dini dalam belajar. Selain metode dan pendekatan, ada juga sejumlah bahan yang harus dipersiapkan oleh guru muatan lokal dalam peningkatan pengembangan mata pelajaran muatan lokal yaitu aneka alat peraga edukatif seperti kartu huruf hijaiyah, kartu kata, kalender do'a harian, aneka gambar pembelajaran seperti gambar wudhu, shalat, manasik hari, dan lain-lain, kumpulan tarikh 25 nabi, aneka kaset CD (cerita nabi, pengenalan amaliyah bidang fiqih, dan lain sebagainya).

\section{Evaluasi}

Evaluasi merupakan bagian dari sistem manajemen. Evaluasi adalah metode penelitian yang sistematis untuk menilai rancangan implementasi dan efektifitas suatu program.

Dalam hal ini, kurikulum juga dirancang dari tahap perencanaan, organisasi kemudian pelaksanaan dan akhirnya evaluasi. Tanpa evaluasi maka tidak akan mengetahui bagaimana kondisi kurikulum tersebut dalam rancangan, pelaksanaan, serta hasilnya.

$$
\text { Evaluasi kurikulum adalah }
$$
penelitian yang sistematik tentang manfaat, kesesuaian efektifitas dan efisiensi dari kurikulum yang diterapkan. Evaluasi kurikulum dapat mencakup 
keseluruhan kurikulum atau masingmasing komponen kurikulum seperti tujuan, isi, atau metode pembelajaran yang ada dalam kurikulum tersebut.

Evaluasi kurikulum dapat menyajikan bahan informasi mengenai area-area kelemahan kurikulum sehingga dari hasil evaluasi dapat dilakukan proses perbaikan menuju yang lebih baik.

Dalam pengembangan kurikulum muatan lokal, RA NU Banat melakukan evalusai setiap hari dalam proses pembelajaran dan di setiap akhir tahun pembelajaran. evaluasi hasil pembelajaran muatan lokal ini disesuaikan atau mengacu pada kurikulum yang berlaku serta mengacu pada perkembangan zaman. Dalam menganalisis hasil penilaian peserta didik tersebut yaitu dengan cara merekap hasil penilaian kemudian ditulis dalam raport.

Selanjutnya, berdasarkan hasil wawancara penulis menyimpulkan bahwa untuk mengetahui tingkat kemampuan dan keberhasilan anak, evaluasi merupakan sebuah keniscayaan yang ahrus dilakukan dalam sebuah proses pembelajaran. Adapun evaluasi pengembangan kurikulum muatan lokal merupakan sebuah proses yang sistematis yang dilakukan untuk mengetahui sejauh mana anak dapat menguasai materi muatan lokal dan mempraktikkannya secar kontinu dalam kesehariannya baik di sekolah maupun di rumah.

Proses evaluasi ini melibatkan anak sebagai objek yang dinilai dan juga gur serta bantuan dari orang tua untuk mengklarifikasi data dan hasil penilaian yang diperoleh tentang kemajuan anak dalam pembelajaran muatan lokal. Bantuan dari orang tua untuk memantau anak selama di rumah turut menunjang keberhasilan pengembangan kurikulum muatan lokal.

Oleh sebab itu, bagi anak usia dini penilaian terhadap proses evaluasi cenderung berupa ungkapan atau narasi tentang perkembangan anak dalam menguasai materi muatan lokal maupun catatan ankedot yang diperoleh dari skala pencapaian harian, mingguan, dan bulanan yang dilaporkan kepada wali murid secara kontinu (setiap akhir bulan dan di akhir semester/ LPAD).

Dalam Permendiknas No. 58 tahun 2009 tentang standar pendidikan anak usia dini, evaluasi diartikan sebagai penilaian, proses pengumpulan dan pengolahan informasi untuk menentukan tingkat pencapaian pengembangan anak yang mencakup:

a. Teknik penilaian (pengamatan, penugasan, unjuk kerja, pencatatan anekdot, percakapan, laporan orang tua, dokumentasi hasi karya, serta deskripsi profil anak.

b. Lingkup; mencakup seluruh tingkatan pencapaian pengembangan peserta didik dan data tentan gstatus kesehatan, pengasuhan, dan pendidikan.

c. Proses; dilakukan secara berkala, intensif, bermakna, menyeluruh, dan berkelanjutan; pengamatan dilakukan saat anak melakukan aktivitas, tim pendidik mengkaji catatan perkembangan anak dan berbagai informasi masuk secara berkala; melakukan komunikasi dengan orang tua tentang anak; dilakukan secara sistematif, terpercaya, dan konsisten; memonitor semua aspek tingkat pencapaian perkembangan anak; mengutamakan proses dampak hasil; pembelajaran melalui bermain dengan benda konkret 
d. Pengelolaan hasil; pendidik membuat kesimpulan dan laporan kemajuan anak, pendidik menyusun dan menyampaikan laporan perkembangan anak secara berkala, laporan perkembangan anak disampaikan kepada orang tua dalam bentuk laporan lisan dan tertulis secara bijak, disertai saran-saran yang dapat dilakukan orang tua di rumah.

e. Tindak lanjut; pendidik menggunakan hasil penilaian untuk mengembangkan kompetensi diri, memperbaik program, metode, jenis aktivitas, alat kebersihan dan kesehatann, serta memperbaiki sarana prasarana. Mengadakan pertemuan orang tua, merujuk keterlambatan perkembangan anak kepada ahlinya melalui orang tua, melayani program pelayanan bagu anak berkebutuhan khusus.

Dari penjelasan diatas, maka dapat diketahui bahwa dalam melaksankan pengambangan kurikulum muatan lokal RA NU Banat selalu mengacu dan sesuai dengan langkh-langkah manajemen yang meliputi perencanaan, pengorganisasian, pleksanaan, dan evaluasi. Dari keempat langkah tersebut, diharapkan pelaksanaan manajemen yang dilakukan RA NU Banatberjalan sesuai tujuan dan programprogram yang direncanakan sesuai dengan harapan.

Keberhasilan manajemen pengembangan muatan lokal dapat dilihat dari keberhasilan pelaksanaan program yang ditentukan dalam perencanaan, pengorganisasian, dan evaluasi manajemen pengembangan kurikulum muatan lokal. Dari segi proses dikatakan berhasil apabila seluruh atau setidak-tidaknya $75 \%$ guru dan tenaga kependidikan serta tenaga pendukung memiliki kompetensi yang meningkat. Dalam hal ini, maka dapat diketahui bahwa proses pengembangan kurikulum muatan lokal yang dilaksanakan di RA NU Banat dikatakan akan berhasil dan berdampak positif pada proses pelaksanaan pembelajaran yang sesuai dengan humas yang berjalan secara efektif dan bermakna.

\section{Faktor Pendukung dan Penghambat}

Dalam melakukan suatu apapun pastilah terdapat faktor pendukung dan penghambat. Berdasarkan paparan data sebagaimana yang telah dijelaskan di atas, maka dapat diketahui bahwa terdapat faktor-faktor yang mempengaruhi pelaksanaan pengembangan kurikulum muatan lokal yaitu:

1. Faktor pendukung

Faktor pendukung yang dimaksudkan adalah faktor yang keberadaannya turut membantu dalam pengembangan kurikulum muatan lokal. Faktor pendukung pengembangan kurikulum muatan lokal ada 2, yaitu faktor internal dan faktor eksternal.

Faktor internal terdiri dari; keaktifan dan perhatian anak untuk ikut menghafal dan melafalkan materi muatan lokal, bakat dan minat yang dimiliki anak, ketelatenan dan kesabaran guru, serta penggunaan media, metode, dan strategi pembelajaran yang bervariasi. Sedangkan faktor eksternalnya adalah adanya kerjasama dengan wali murid untuk mendampingi anak saat pembelajaran.

2. Faktor penghambat

Faktor penghambat adalah faktorfaktor yang keberadaannya akan mengganggu terhadap usaha pencapaian tujuan pengembangan kurikulum muatan lokal. Faktor penghambat pengembangan kurikulum muatan lokal 
ada 2, yaitu faktor internal dan faktor eksternal.

Faktor internal terdiri dari; keberagaman karakteristik, bakat, minat, kecerdasan, dan kemampuan anak yang berbeda serta keterbatasan penggunaan IT bagi beberapa pendidik. Sedangkan, faktor eksternalnya adalah adanya wali murid yang bersikap acuh tak acuh dan cenderung pasif dan pasrah menyerahkan anak sepenuhnya kepada pihak sekolah.

\section{SIMPULAN}

Perencanaan pengembangan muatan lokal di RA NU Banat dilaksanakan di setiap awal tahun pelajaran dengan menyusun KTSP terbaru dan materi muatan lokal yang disesuaikan dengan kurikulum Kemenag Kudus. Pengorganisasian pengembangan kurikulum muatan lokal dikelompokkan berdasarkan usia peserta didik dan diajarkan secara klasikal di dalam kelas sesuai dengan jadwal mulok yang ada. Pelaksanaan pengembangan kurikulum muatan lokal di RA NU Banat ditangani secara profesional oleh stakeholder dengan memperhatika keseimbangan dengan KTSP yang meliputi; 1) karakteristik kurikulum muatan lokal yang mencakup ruang lingkup bahan ajar, tujuan, fungsi, dan sebagainya, 2) strategi implementasi, yaitu strategi yang digunakan dalam implementasi kurikulum muatan lokal yaitu dengan pendekatan melalui belajar sambil bermain dan alat bantu peraga. Evaluasi pengembangan kurikulum berlangsung di dalam proses pembelajaran yang dilakukan setiap hari, karena sebagian besar materi muatan lokal merupakan amaliyah atau kaifiyah dan penanaman nilai-nilai ahama yang terbentuk lewat pola pembiasaan.
Pengembangan kurikulum muatan lokal di RA NU Banat dipengaruhi oleh beberapa faktor seperti, karakteristik anak, bakat dan minat anak, tingkat kecerdasan anak, penggunaan IT oleh tenaga pendidik, serta kerjasama dari orang tua siswa.

\section{DAFTAR PUSTAKA}

Dakir. (2009). Perencanaan Dan Pengembangan Kurikulum. Jakarta: PT. Rineka Cipta.

Hamalik, O. (2005). Kurikulum dan Pembelajaran. Jakarta: PT Bumi Aksara.

Minarti, S. (2011). Manajemen Sekolah: Mengelola Lembaga Pendidikan Secara Mandiri. Yogyakarta: ArRuzz Media.

Mulyasa, E. (2002). Kurikulum Berbasis Kompetensi: Konsep, Karakteristik, dan Implementasi. Bandung: PT Remaja Rosdakarya.

Mulyasa, E. (2007). Kurikulum Tingkat Satuan Pendidikan: Sebuah Panduan Praktis. Bandung: Remaja Rosdakarya.

Nurdin, S., \& Usman, M. B. (2003). Guru Profesional dan Implementasi Kurikulum. Jakarta: Ciputat Press.

Rusman. (2011). Manajemen Kurikulum. Jakarta: PT Raja Grafindo Persada.

Satori, D., \& Komariah, A. (2011). Metode Penelitian Kualitatif. Bandung: Alfabeta.

Sudjana, N. (2011). Pembinaan Dan Pengembangan Kurikulum Di Sekolah. Bandung: CV. SinarBaru.

Susilo, M. J. (2007). Kurikulum Tingkat Satuan Pendidikan: Manajemen Pelaksanaan dan Kesiapan Sekolah Menyongsongnya. Yogyakarta: Pustaka Pelajar.

Tim Redaksi Ma'arif Press. (2006). Kompilasi Kebijakan Pendidikan Nasional ( $1^{\text {re }}$ éd.). Semarang: PW LP NU Jawa Tengah.

U.M. Saefullah. (2012). Manajemen Pendidikan Islam. Bandung: Pustaka Setia. 